\title{
Issues of Substance Abuse Among Schooling Adolescents: Approaches and Solutions
}

\author{
Noor Azian Binti Abd. Hani* \\ Universiti Kebangsaan Malaysia \\ Selangor, Malaysia \\ p90207@siswa.ukm.edu.my*
}

\author{
Salleh bin Amat \\ Universiti Kebangsaan Malaysia \\ Selangor, Malaysia \\ Sallehba@ukm.edu.my
}

\author{
Mohd. Izwan Mahmud \\ Universiti Kebangsaan Malaysia \\ Selangor, Malaysia \\ izwan@ukm.edu.my
}

\begin{abstract}
The increase in substance abuse data among teenagers is alarming in today's society. The current imbalance in the state of modernity and spirituality in the formation of identity among adolescents causes these groups to be involved in substance abuse. Lack of knowledge of the risk and protective factors in the use of substance abuse is also seen as a factor in society's view of this issue as an insignificant social problem and is becoming more prevalent each year. In the context of primary and secondary schools, the Ministry of Education Malaysia and the National Anti-drug Agency should consider a holistic and effective approach to implementing various prevention and rehabilitation programs through the Drug and Public Safety Education Guidelines aimed at providing knowledge, awareness and understanding to school children, teenagers, parents, the community and the community on the risk of drug abuse and make it a "Drug Free State". As such, this paper will provide insights into the modules of rehabilitation in substance abuse and spiritual therapy that need to be given to reduce substance abuse cases along with adding value to adolescents in particular.
\end{abstract}

Keywords-substance abuse, spirituality, risk factors, protective factors, identity

\section{INTRODUCTION}

Drugs is not a new concept in today's world, but they are one of the most critical social problems faced by countries as early as the 70 's. Various labels are directed to drugs such as stools, disgusting, illegal and so on but they do not have any impact still. Drug addiction in Malaysia is also becoming more distressing which is not only leading to self-destruction, but also leading to more serious social problems that can threaten the peace, harmony and development of a country. This phenomenon is particularly detrimental to the country, especially when a significant number of youths are looked upon as the next generation to shape the nation's future development [1].

In the context of primary and secondary schools, the Ministry of Education Malaysia and the National Antidrug Agency have implemented various prevention programs through the Drug and Public Safety Education Guidelines aimed at providing knowledge, awareness and understanding to students, IPT students, teens, parents and the community about the risk of drug abuse and make it the
"Drug Free country of the Year". However, it seems that there is no holistic approach and solution that can impact students' self-avoidance in the matter of substance abuse.

According to the National Anti-Drug Agency (AADK) Report 2014-2018, the Number of Addicts Detected by Age, 13-18 years old has consistently been the highest. While drug abuse statistics also shows that peer influence dominates as a major factor in adolescent involvement in substance abuse other than curiosity, pleasure, stress and more. Stated that peer influence and the nature of the temptation to try new things are the reasons why adolescents attempt drugs. It is this group of teenagers who need to be approached and given attention in restoring their well-being [1].

The concept of self-determination needs to be explored in order to develop a strong identity as well as the ability to make the right decisions in their lives. This will prevent this group from getting into the misuse of substances. Thus, this concept paper will also address the issue of substance abuse among schooling adolescents: Approaches and Solutions. Just as how the human body needs nourishment and nutrients to be healthy and energetic, so is spirituality. It certainly requires careful care and treatment to remain healthy and positive in everyday life. This spiritual power is very much needed by man to control himself against such negative matters such as drug abuse [2].

The symptoms of substance abuse are often linked to educational factors and adolescents' own behavior. In addition, the social problems that effect adolescents are now often regarded as the failure of an educational system in terms of students' personal and educational development. Recent studies on the importance of the education system in the development of personality also indicate that educational factors are an important element in the process of adolescent socialization where attitudes, values and belief systems are embedded in the adolescent mind. If positive inputs are not properly utilized and properly applied by adolescents, then they are at risk of being caught up in drug abuse.

The factors that may cause adolescents to engage in drug abuse are lack of motivation, self-confidence, selfconcept, over-reliance on fate and not effort along with pressure from within parents and family [3]. In addition, the 
concept of self-concept is also an important process besides the process of acquiring knowledge.

\section{Review of past research}

Substance abuse refers to the misuse or use of illegal substances such as drugs or narcotics, alcohol and various substances in quantities or in ways that may be harmful to individuals or others [4]. In the context of drug addiction, the Diagnostic and Manual sections Mental Illness Statistic (DSM), The United States Psychiatric Association and WHO no longer use the term substance abuse but instead they use the term substance abuse more broadly and the harm it causes the consumers. Substance abuse is very synonymous with adolescents especially among adolescents that are at-risk. Today substance abuse is one of the most important public health issues and is associated with a variety of behavioral and mental health issues [5]. One of the most relevant factors affecting the increase in substance abuse is when drugs are taken at a very young age. If someone takes drugs at a very young age the risk of being involved in their abuse and addiction is high. Recent developments shows that substances which are not considered to be illegal drugs under the law is now renewed as abusive substances. Even substance abuse like marijuana can pave the way for more serious addiction problems like cocaine or heroin [5].

An adolescent can be considered as at-risk if he or she has characteristics such as engaging in wrongdoing by law, community norms or being in an environment that may encourage him or her to engage in wrongdoing. They are the ones who find it difficult to adapt and one of the early signs is risking themselves by engaging in school cases that can cause disciplinary actions. The highest proportion of adolescent addicts that are involved in substance abuse are aged 19-39 years old, while adolescents between 13-18 years of age shows a significant increase. A study by Mardzelah (2012), Isaac (2012), Siti Hairaney (2004), found that among the causes of student misconduct is due to religious factors such as lack of spiritual practice and religious appreciation. A study by Abu Mansor Mat Urdi (2005) also found that students who regularly practice religion in their lives are less likely to commit any wrongdoings in school [6].

This statement is in line with Othman Najati's (1992) view that the crisis facing mankind today exists because of their deviation from religion and spiritual values. In fact, Hassan Langgulung (1983) in his study also found that young men and women are in need of religion such as deepening Quranic knowledge, wanting to draw closer to Allah S.W.T and having a fear of being tormented in the hereafter. Zulkefli (2007) in his study suggested that a spiritual approach is best practiced because most students today are deficient in spiritual aspects. Nor Aida (1997) University of Malaya (UM) in its scientific study: The social symptoms of adolescents: a study in Felda Kumai, Triang, Pahang concluded that adolescents today want to live independently without being under their parents' collar. They are not good at taking advantage of the freedom they are given, they rather spend their time looking for entertainment [1].

\section{DISCUSSION}

\section{Definition of Substance Abuse}

Substance abuse often occurs in adolescents. Among the most commonly abused substances are cigarettes, alcohol, glue, turpentine, cough medicine and drugs. Misuse of materials means the use of substances that may be excessively addictive or for any purpose other than the actual purpose. Abuse is a person's use of any substance that is intended to cause physical harm characterized by behavior or other responses. A person's involvement in substance abuse is due to repeated or periodic urges to use psychiatric drugs and at the same time avoid symptoms of withdrawal due to its absence. Therefore, the act of abusing substances is morally and legally wrong as it can be detrimental to health and make one lose their judgment. This situation can be harmful to oneself and others [7].

\section{Adolescents}

According to the Peer Guidance book, Aminuddin Baki Institute, Teenagers are between the age 12 to 18 yearold. Adolescents as; "the transition between childhood and adulthood [8]. During this time the child experiences both growth and physical development as well as his or her psychological development. They are not children in the form of bodies or ways of thinking or acting, but are not mature adults yet." Adolescents is defined as a period of developmental transition between childhood and adulthood biologically, cognitively, and also social-emotional change. Adolescents begin at the age of 15- 21 years with an everpresent desire and a sense of urgency, and a habit of trying something new in their lives. If they are not controlled and restrained, they will fall out of the way [9].

\section{Risk Factors}

Defined as a characteristic and symptom of an individual that is statistically related to an increased incidence of disease. Risk factors are factors that exist before symptoms occur. In this context, risk factors include both internal and external factors that contribute to a teenager being caught up in substance abuse [10].

\section{Challenges and Reality}

Adolescents are often portrayed as vulnerable and have always wanted freedom in their own right. They feel that they are wise enough to evaluate the good without any intervention from a parent. In examining the social situation of adolescents today, various aspects need to be explored as to the true cause of why and how negatively the symptoms are increasingly affecting the image of adolescents themselves. Among the factors identified are the lack of application of spiritual / religious knowledge. As such, this concept paper will outline some of the elements needed when it comes to rehabilitation for adolescents who have been involved in substance abuse. Strong spiritual life not only prevents a person from engaging in drugs, but can also provide effective treatment and recovery for drug addicts. More than $70 \%$ of drug addicts in Malaysia are Muslims. The question is whether they are just Muslims by title or Muslims practicing Islamic teachings. If they were the ones 
who really practiced their life according to Islamic teachings, this would not have happened [1].

\section{Objective}

Based on the above discussions, it is clear that there is a need for a spiritually oriented rehabilitation module is enforced and implemented. However, the remedial approach needs to be based on the curriculum in the Ministry of Education Malaysia (MOE) and targeted at teenagers involved in substance abuse issues. It is an important step in the socialization and value addition of adolescents especially in relation to their responsibilities in the true sense of Islam.

\section{Approaches \& Solutions}

According to the Salaf Soleh morality is religion and religion is like unto morality. According to Ibn Qayyum every building has its foundation and Islam is like unto a foundation of a building. Scholars are not unanimous in the sense that the noble character is the fruit of faith and has the true power of prayer. Whereas bad behavior produces weakness in the faith such as drinking alcohol.

This statement clearly demonstrates that morality is closely related to humans. As an example, morality of the Rasulullah s.a.w is the Quran. Adolescents with good morals can bring themselves and their companions towards truth and happiness as they seek out good friends and good morals. Adolescents who leaves their family to live independently will begin following their lust constantly to change their lives to the point that they are capable of such vile things such as smoking, drug addiction, free association of men and women, open sex, childbirth Out-of-wedlock and others that puts their own family to shame.

Humans and morals are inseparable regardless of age. Each act or act of one's actions or actions taken by a person does not escape or emerge from a good or bad environment, whether conscious or not. Adolescents who have a good religious education from both their parents, teachers and so on can think positively about what they will do on a daily basis, but if they do not, these teenagers will do things according to their passions without regard for the good or bad in themselves which results in the destruction of the teenager [6].

\section{Approach to Module Fitrah}

The spiritual approach through the Fitrah Module needs to be established and implemented in the rehabilitation programs for adolescents. The approach of this module is based on the human lifestyle fitrah which is compatible with the natural human fitrah and the embodiment of fitrah is emanated as mankind often prioritizes good and avoids evil deviation, and that is what Islam demands. The word fitrah actually has various meanings and one of such is by Ibn Qayyum which means a result of creation which is also referred to as sunnah, incident or habit.
In this context, adolescents need to be clear about the creator God who created them and the only One who knows their inclinations, desires, habits, and goals. It is on this basis that human beings naturally complement each other's needs. That is the rule of fitrah that God created.

In other words, the construction of this module should bring back the focus on how to understand oneself and God while understanding that each human being is created holy, good and inclined to good because they come from God. It is therefore natural for the whole human life to operate on the basis of fitrah and accept the fact that it is in accordance with the rules of Allah, not that of man. This is the essence of the nature of fitrah in Islam and as long as mankind obeys the nature of fitrah as Islam demands, they will be guided towards truth and goodness. It is common to hear expressions of a healthy lifestyle and a positive lifestyle, however, a lifestyle of fitrah does not only promote a healthy and positive lifestyle, but also follows a lifestyle that does not go beyond the foundations of Islamic law.

\section{CONCLUSION}

Indeed, there is no shortcut in solving social issues, especially on issues of substance abuse among adolescents unless going back to religious teachings. Indeed, Islam is a religion of welfare and security. This is precisely and in accordance with the word of Islam itself, which is derived from the Arabic word, salima or salama which means safe, secure and prosperous. It is time for us to re-introduce the religious approach in our daily lives and ensure that all social challenges can be effectively overcome.

\section{REFERENCES}

[1] Agensi Antidadah Kebangsaan, 2007 Jurnal Antidadah Malaysia, Kementerian Dalam Negeri.

[2] Abdul Halim b. Mohd. Hussin et. Al, (2009/2010). Projek Penyelidikan Agensi Antidadah Kebangsaan \& Universiti Sains Islam Malaysia

[3] Rosnah binti Manap (2013). Kajian Faktor Risiko Belia Terlibat Dengan Penyalahgunaan Bahan Di Kawasan Bandar Di Negeri Johor. Sarjana Pendidikan Bimbingan \& Kaunseling, Universiti Teknologi Malaysia

[4] Amin Johari Ghazali (1995). Kesan Latihan Kemahiran Sosial Terhadap Konsep Kendiri Pelajar, Universiti Utara Malaysia, Diambil pada 28 Mac 2009 daripada HTTP://WWW.PDF SEARCHENGINE.COM/KONSEP KENDIRI-PDF.HTML

[5] Agensi Antidadah Kebangsaan, (2007). Dadah Musuh No. 1 Negara, Kementerian Dalam Negeri.

[6] Rozmi Ismail, Nor Azri Ahmad, Fauziah Ibrahim \& Salina Nen (2017). Pengaruh Faktor Individu, Keluarga dan Persekitaran Sosial Terhadap Tingkah Laku Penyalahgunaan Bahan dalam Kalangan Remaja. Akademika 87(1), April 2017:7-16.

[7] Jamaludin Ahmad. (2007). Modul \& Kaunseling Penyalahgunaan Dadah ; Universiti Putra Malaysia

[8] Daradjat, Zakiyah. (1990). Kesehatan Mental. Jakarta: Gunung Agung.

[9] Santrock, John W. (2003). Adolescence. Perkembangan Remaja. Edisi Keenam. Jakarta: Erlangga.

[10] Bustan, M.N., (2000) . Epidemiologi Penyakit Tidak Menular. PT Rineka Cipta, Jakarta. 